\title{
Population sampling of the golden mussel, Limnoperna fortunei (Dunker, 1857), based on artificial ceramic substrate
}

\author{
Paulo Eduardo Aydos Bergonci * \\ Maria Cristina Dreher Mansur \\ Daniel Pereira \\ Cíntia Pinheiro dos Santos \\ Centro de Ecologia, Universidade Federal do Rio Grande do Sul \\ Av. Bento Gonçalves, 9500, Setor 4, Prédio 43422, Sala 102 \\ CEP 91540- 000, Porto Alegre - RS, Brasil \\ *Autor para correspondência \\ paulobergonci@gmail.com
}

Submetido em 12/02/2009

Aceito para publicação em 26/05/2009

\section{Resumo}

Amostragem populacional do mexilhão dourado, Limnoperna fortunei (Dunker, 1857), com base em substrato artificial cerâmico. Foi testado o substrato cerâmico $(21 \mathrm{~cm}$ de comprimento, $6 \mathrm{~cm}$ de largura e $1,3 \mathrm{~cm}$ de espessura) na amostragem de populações de Limnoperna fortunei em duas estações de coleta no delta do rio Jacuí (Canal do Jacuí (CJ) e Cais do Porto (PO)), RS. Sobrepondo ao substrato uma malha quadriculada $\left(1 \mathrm{~cm}^{2}\right)$ e segmentada $\left(\mathrm{s}_{\mathrm{I}}, \mathrm{s}_{\mathrm{II}}\right.$ e $\left.\mathrm{s}_{\mathrm{III}}\right)$ foram quantificados os indivíduos. Por meio de Kruskal-Wallis e Mann-Whitnney, foram comparadas as densidades médias de recrutas e adultos, em cada segmento, superfície (lisa e canaliculada) e estação de coleta $(\alpha=0,05)$. No CJ, os segmentos extremos e o intermediário (adultos) diferiram estatisticamente $(\mathrm{p}<0,0001)$, assim como, as superfícies (recrutas) $(\mathrm{p}=0,04)$ do substrato cerâmico. As densidades de recrutas e adultos entre os locais CJ e PO também se diferenciaram entre si $(\mathrm{p}<0,0001)$. O método foi eficiente na amostragem de populações da invasora.

Unitermos: invasora, macroaglomerados, monitoramento, subamostragem, superfícies

\section{Abstract}

The ceramic substrate $(21 \mathrm{~cm}$ in length, $6 \mathrm{~cm}$ in width and $1.3 \mathrm{~cm}$ in depth) was tested for the Limnoperna fortunei population, sampling at two localities in the Jacuí delta (Jacuí Canal (Canal do Jacuí - CJ) and Port Docks (Cais do Porto - PO)) in Rio Grande do Sul state, Brazil. The individuals were quantified through the superimposition of a squared $\left(1 \mathrm{~cm}^{2}\right)$ and segmented $\left(\mathrm{s}_{\mathrm{I}}, \mathrm{s}_{\mathrm{II}}\right.$ e $\left.\mathrm{s}_{\mathrm{III}}\right)$ sheet on the substrate. Using Kruskal-Wallis and Mann-Whitnney, the recruit and adult average densities were compared in each segment, surface (smooth and pipe-shaped) and sampling locality $(\alpha=0.05)$. In CJ, the extreme and intermediate (adult) segments differed statistically $(p<0.0001)$, as well as the ceramic substrate surfaces (recruits) $(p=0.04)$. The recruit and adult densities between the CJ and PO localities also differed between themselves ( $p<0.0001)$. The method was efficient for the invasive population sampling.

Key words: invasive, macroclusters, monitoring, subsampling, surfaces 


\section{Introduction}

The golden mussel, an invasive bivalve of Asian origins, was brought to the continental waters of South America via ballast water (Pastorino et al., 1993). In Brazil, it was first recorded in the Guaíba Lake, in Porto Alegre, Rio Grande do Sul state (Mansur et al., 1999). The environmental (landscape, aquatic flora and fauna) and economic (constructed systems) damages, resulting from the proliferation of the invasive species, were widely recorded (Darrigan and Mansur, 2006; Mansur et al., 2003; 2004).

The golden mussel (Mytiloida) produces byssus threads, which allow the formation of compact macroclusters on hard substrates. This feature differentiates them from other native bivalves of the south of Brazil (unionids and venerids) which live burrowed in sandy substrates, with the exception of the byssus-bearing species Eupera Bourguinat, 1854, which do not create macroclusters (Mansur and Pereira, 2006).

Due to the variability of substrates to which the mussel adheres, the comparison of samplings carried out through traditional gathering methods (dredges and square frames) becomes very difficult. As for the artificial substrates, they standardize sampling, reduce variability and sample processing time (Gibbons et al., 1993). Artificial substrates were widely used for the monitoring of the invasive species Dreissena polymorpha (Pallas, 1771), the zebra mussel, in limnic ecosystems in North America (Claudi and Mackie, 1994).

Various types of artificial substrates have been used in the monitoring of L. fortunei populations, such as three-dimensional asbestos structures (Morton, 1977), PVC adaptations (Boltovskoy and Cataldo, 1999), wood (Fontes et al., 2002; Mansur et al., 2009) and PVC (Darrigran et al., 2007) both in the shape of an " $\mathrm{X}$ " and PET bottles (Faria et al., 2006). Mansur et al. (2003) used ceramic substrates (six-hole commercial bricks), for the first time, to sample L. fortunei populations in the Guaíba Lake, in Porto Alegre. Santos (2004) and Santos et al. (2008) continued the monitoring of the Lake with ceramic substrate, identifying and quantifying different life stages of the invasive species, on the substrate. Later, the use of ceramic substrate (commercial brick) was adopted by FURNAS Central Hydroelectric Plants and by FEPAM (Fundação Estadual de Proteção Ambiental - State Foundation of Environment Protection) (Terra et al., 2007).

Monitoring golden mussel population densities is one of the main goals of the invasive species handling projects, but monitoring efficacy requires adequate methods of sampling and subsampling.

Aiming to test a sampling and subsampling method which would result in significant information on the life cycle stages of recruits and adults of L. fortunei, experiments were carried out in the Jacuí River Delta (Municipality of Porto Alegre, Rio Grande do Sul state), using ceramic artificial substrate.

\section{Material and Methods}

The study area (Figure 1) is located in the Jacuí River delta, in the Rio Grande do Sul State Central Depression physiographic unit, in the Porto Alegre metropolitan region. The Jacuí River debouches into the Guaíba Lake through an inner delta created by a series of distributaries, among which the Jacuí Canal stands out (average depth: $8 \mathrm{~m}$ ). In the Port Docks, near the Porto Alegre urban area, the peripheral landscape has been significantly altered with land filling. Steep shores (concrete walls) and deep waters $(5 \mathrm{~m})$ are presently found in this locality.

The sampling localities are in the Jacuí River delta, on the right shore of the Jacuí Canal (CJ), on Pintada Island and in the Port Docks (PO), downtown Porto Alegre. After analyzing the historical data of larval densities in Guaíba Lake (Santos, 2004) and in the lower Paraná River (Boltovskoy and Cataldo, 1999), the period from December 2005 to March 2006 was determined for the execution of the artificial substrate exposure experiments, the period in which the highest larval production and recruitment occurs. The period of exposure (three months) is the minimum necessary for colonization (recruits) and development of specimens (adults).

In the same period, monthly samplings of larvae (30L) were made in both sampling localities with a 


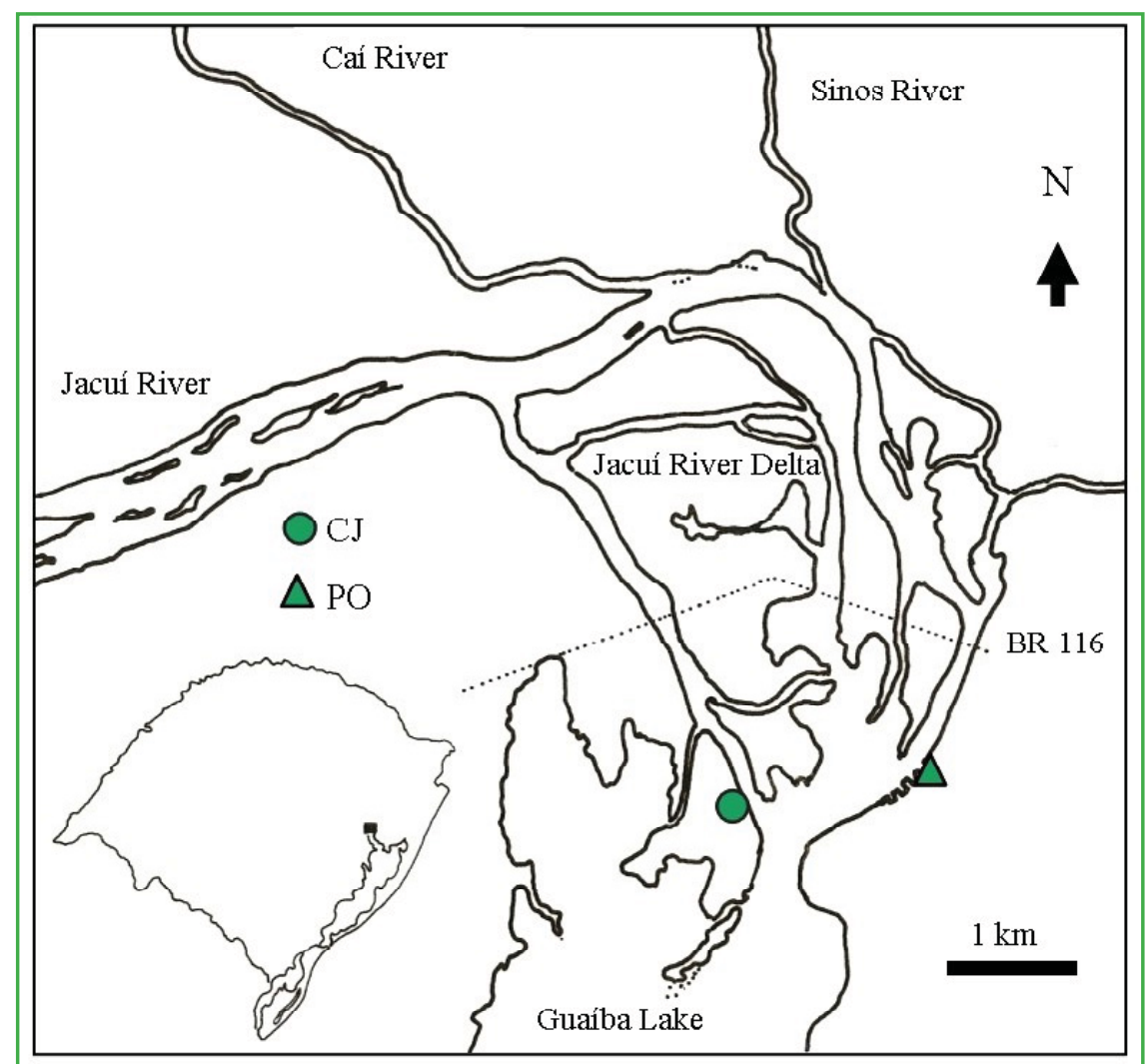

FIGURE 1: Sampling localities in the Jacuí Canal, on Pintada Island (CJ: 3000`48,29”S; 51¹5’36,46”W) and in the Port Docks (PO: $30^{\circ} 01$ '31,08”S; 51¹3’38,26”W) (Jacuí River delta, Rio Grande do Sul state, Brazil).

plankton net $(30 \mu \mathrm{m})$, in accordance with Santos et al. (2005). The monitoring of larval densities was used as a potential recruitment indicator.

The chosen substrate consisted of a commercial refractory brick, $21 \mathrm{~cm}$ in length, $6 \mathrm{~cm}$ in width, and $1.3 \mathrm{~cm}$ in thickness (Figure 2). One side of the substrate presented a smooth surface (Figure 2a) and the other side was pipe-shaped (2b). The bricks were perforated at $2 \mathrm{~cm}$ from their extremities (Figure 2). They were attached to the frames through this hole, with plastic rings.

In December (2005), nine replicas of ceramic substrate were exposed in each sampling locality, attached to metal structures (iron frame) through plastic rings. In CJ, the frames were suspended with ropes on the lower part of a wharf. Therefore, both surfaces remained equally exposed to the water column. In PO, the iron frames were suspended with ropes near the dock's concrete wall. The smooth surface of the substrate was positioned in front of the concrete wall, while the pipeshaped surface remained exposed to the water mass. In

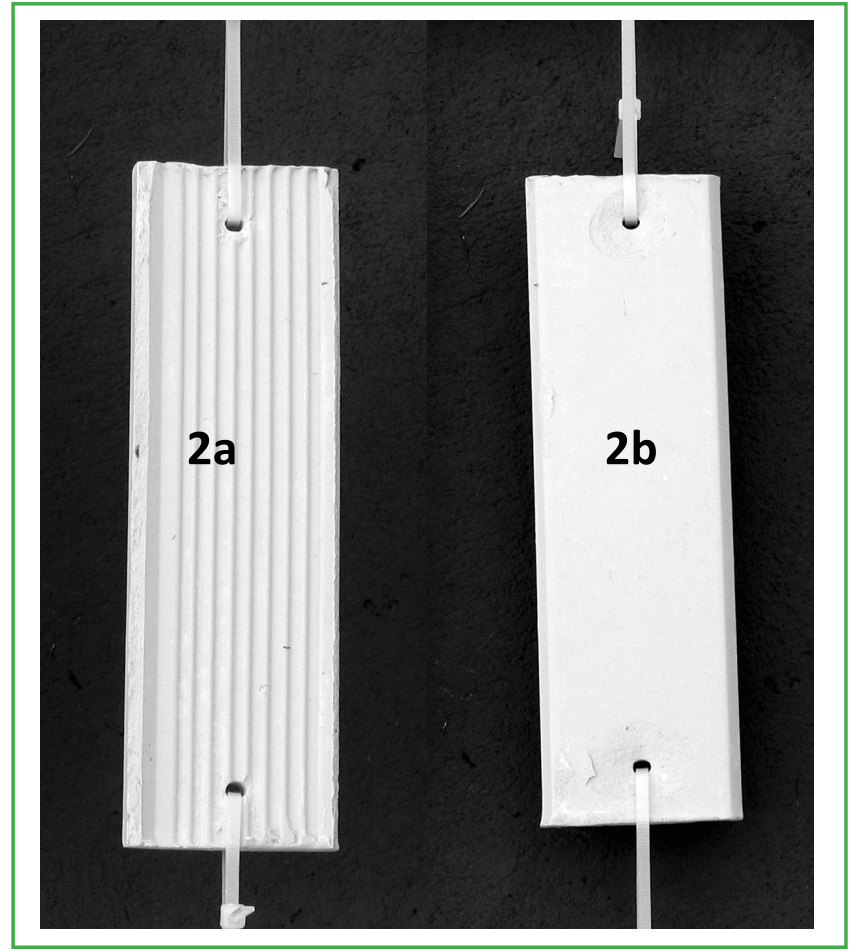

FIGURE 2: Ceramic substrate (small commercial brick, 21x $6 \mathrm{~cm}$ ): smooth surface (2a); pipe-shaped surface (2b). 
March, all substrates were collected from the water and transported to the laboratory.

The larva samples were fixed with alcohol $96^{\circ} \mathrm{GL}$ and transported to the laboratory. Monthly water samplings were made in each of the sampling localities in order to analyze physical, chemical (water temperature, $\mathrm{pH}$, turbidity, oxygen chemical demand, dissolved oxygen, total phosphorus and nitrate) and microbiological (fecal coliforms) indicators, in accordance with the described APHA (2004) methods.

The larvae were quantified (ind. $\mathrm{m}^{-3}$ ) in accordance with Santos et al. (2005). The bricks were dehumidified in a Pasteur oven $\left(60^{\circ} \mathrm{C}\right)$ and then examined under a stereoscopic microscope for quantification.

According to Santos et al. (2008), recruits and adults presented, respectively, $<0.5$ and $\geq 0.5 \mathrm{~mm}$ in length. The quantification took place in these two stages, through a stereoscopic microscope with a millimetric lens and transparent grid (Figure 3) superimposed on both substrate surfaces. In each segment of the grid, five squares $\left(Q_{\mathrm{ij}}\right)$ of $1 \mathrm{~cm}^{2}$ were randomly picked, on which the recruit and adult individuals were quantified. Through equation $1\left(D s_{n}=\left(\Sigma Q_{i j} / 5\right)\right)$ the individual densities were calculated (ind. $\mathrm{cm}^{-2}$ ) for the three segments

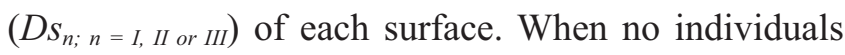
were detected in the squares of a segment, the total quantification of individuals was made in the segment, dividing the resulting quantification value by the segment area $\left(42 \mathrm{~cm}^{2}\right)$. Then, surface densities were obtained $\left(D l_{n ; n=\text { smooth, Iorpipe-shaped, II }}\right)$ through equation $2\left(D l_{n}=\mu D s_{n}\right)$. The average density $\left(D\right.$, ind. $\left.\mathrm{cm}^{-2}\right)$ of individuals on the ceramic substrate was obtained through the sum of both surface densities, using equation $3\left(D=\Sigma D l_{n}\right)$.

The average density in the segments was considered as a replica. In order to verify significant differences between average densities in different segments $\left(D s_{\mathrm{I}}\right.$, $D s_{\text {II }}$ e $D s_{\text {III }}$ ) of the brick, the non-parametric KruskalWallis test was used, followed by multiple comparisons using the Dunn method $(\alpha=0.05)$. Through the MannWhitnney test $(\alpha=0.05)$, the average densities (ind. $\mathrm{cm}^{-2}$ ) of substrate surfaces $\left(\mathrm{H}_{0}: D l_{1}=D l_{2}\right)$, sampling localities $\left(\mathrm{H}_{0}: D(\mathrm{CJ})=D(\mathrm{PO})\right)$ and population components $\left(\mathrm{H}_{0}\right.$ : $D$ (recruits) $=D$ (adults)) were compared. Substrate segments, as well as surfaces, were tested using only CJ data, where surfaces remained equally exposed to the water column. Non-parametric tests were chosen after verifying that the data was not normal, through the Kolmogorov-Smirnov test for one sample $\left(\mathrm{H}_{0}\right.$ : data follows normal distribution), with a $95 \%$ significance level, according to Zar (1999). The water quality indicators were compared between localities using the Mann-Whitnney test $(\alpha=0.05)$. The Kruskal-Wallis test was obtained through the BIOESTAT 3.0 software, while the Mann-Whitnney and the Kolmogorov-Smirnov tests were obtained using the SPSS 11.5 software.

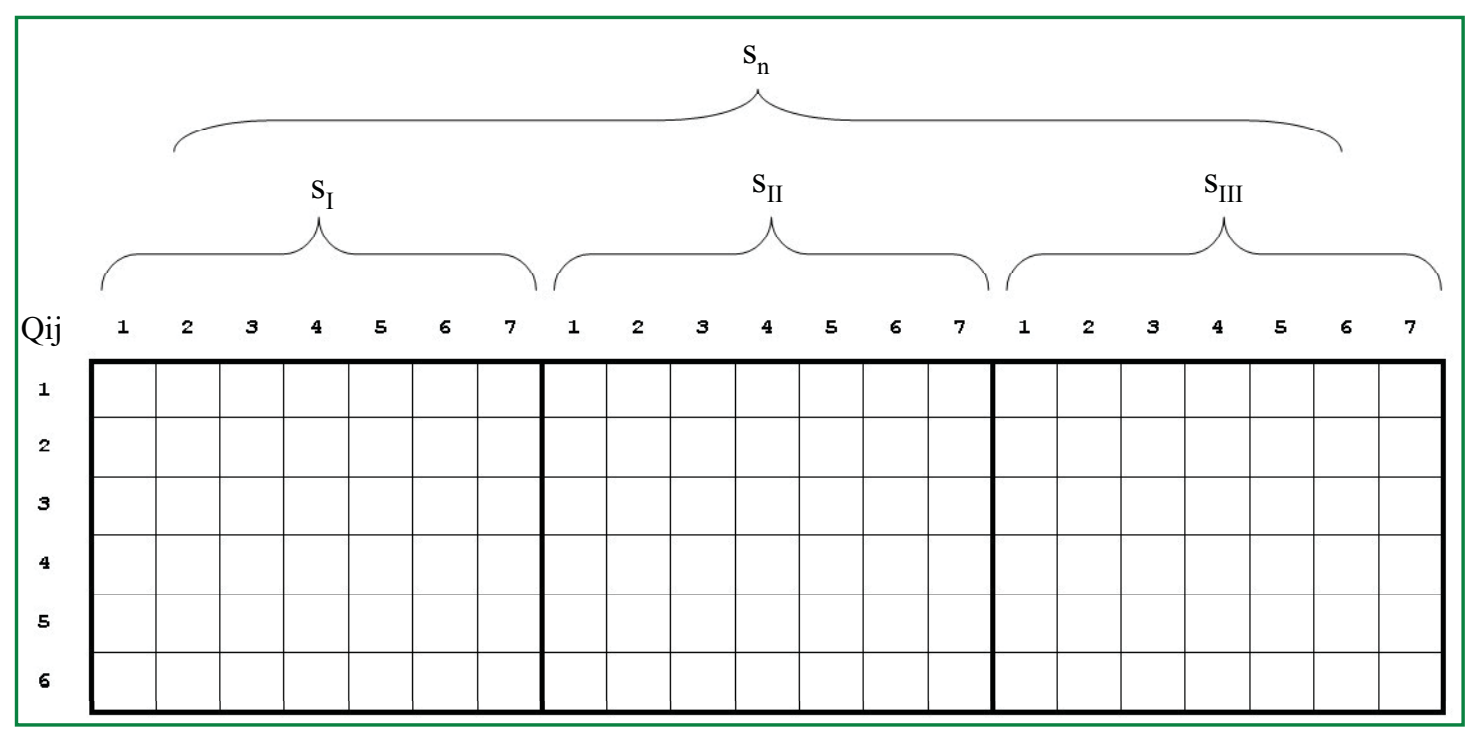

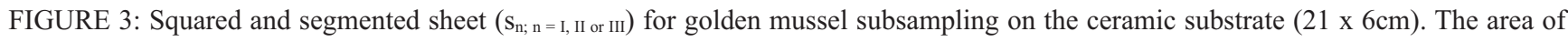
each square $\left(Q_{i j}\right)$ is $1 \mathrm{~cm}^{-2}$. 


\section{Results and Discussion}

\section{Larval density}

The Jacui Canal presented the highest larval densities (Figure 4), with maximum values in the months of December and January. Significant differences were verified $(p=0.08)$ among $C J$ and PO, considering $\alpha$ $<0.1$. In the period of the experiment, the average density (ind. $\mathrm{m}^{-3}$ ), the standard error, and the minimum and maximum larval densities in $\mathrm{CJ}$ were, respectively, $7208.3 \pm 2026.1(1500.0-11066.6)$ and in PO, 2000.0 \pm 751.7 (700.0 - 3866.7).

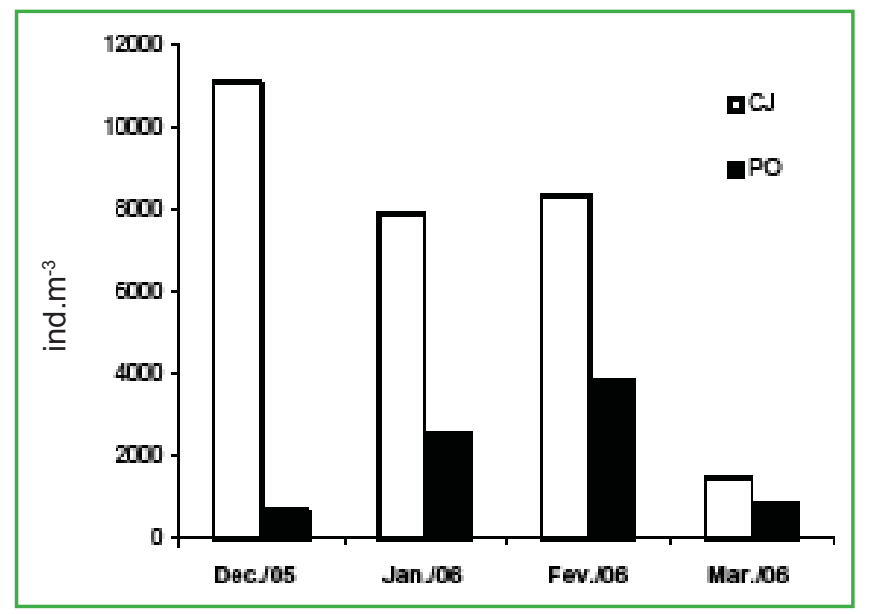

FIGURE 4: Limnoperna fortunei larval density (ind. ${ }^{-3}$ ), in the Jacuí Canal on Pintada Island (CJ) and in the Port Docks (PO) (Jacuí River delta, Rio Grande do Sul state, Brazil).

\section{Ceramic substrate}

Recruit and adult individuals showed a differentiated pattern of distribution on the tested substrate surfaces (Figure 5).

\section{Substrate segments}

The sampling number, the average recruit density (ind. $\mathrm{cm}^{-2}$ ), the standard error and the minimum and maximum values observed in the three ceramic substrate segments (Figure 6a) were, respectively: $\mathrm{s}_{\mathrm{r}}, \mathrm{n}=30.00$ and $8.63 \pm 2.15(0.00-41.20) ; \mathrm{s}_{\mathrm{II}}, \mathrm{n}=30.00$ and $9.81 \pm 2.52$ $(0.00-45.00)$ and $\mathrm{s}_{\mathrm{III}}, \mathrm{n}=30.00$ and $9.44 \pm 2.50(0.00-$ 50.00). The Kruskal-Wallis test (Dunn a posteriori) did not present significant differences $(\mathrm{p}=0.971)$ between the average densities of golden mussel recruits on the three ceramic substrate segments. Similarly, when compared to the average recruit densities on the exposed substrates in CJ, no significant differences $(p=0.879)$ were found. The respective average values for density, standard error, minimum and maximum were (Figure 6b): $\mathrm{s}_{\mathrm{I}}, \mathrm{n}=2.00$ and $19.87 \pm 3.32(0.00-41.20) ; \mathrm{s}_{\mathrm{II}}, \mathrm{n}=$ 12.00 and $23.22 \pm 3.82(7.20-45.00)$; and $\mathrm{s}_{\mathrm{III}}, \mathrm{n}=12.00$ and $22.27 \pm 4.03(6.40-50.00)$.

The sampling number, the average adult density (ind. $\mathrm{cm}^{-2}$ ), the standard error and the minimum and maximum values for the three ceramic substrate segments (Figure 6a) were, respectively: $\mathrm{s}_{\mathrm{I}}, \mathrm{n}=38.00$ and $1.25 \pm 0.32(0.00-5.60) ; \mathrm{s}_{\mathrm{II}}, \mathrm{n}=38.00$ and 0.30 $\pm 0.11(0.00-2.80)$; and $\mathrm{s}_{\mathrm{III}}, \mathrm{n}=38.00$ and $1.13 \pm$ 0.31 (0.00 - 6.80). The Kruskal-Wallis test (Dunn a posteriori) did not present significant differences $(\mathrm{p}=$ 0.057 ) between average densities of adult individuals on the three segments of the brick, even considering a predominance of adult individuals in the segments $\mathrm{s}_{\mathrm{I}}$ and $\mathrm{s}_{\mathrm{III}}$ (Figure 5b, 5c). On the other hand, when compared only to the average densities of the exposed substrates in $\mathrm{CJ}$, a significant difference was verified, with segments $\mathrm{S}_{\mathrm{I}}$ and $\mathrm{s}_{\mathrm{III}}$ differing from $\mathrm{s}_{\mathrm{II}}(\mathrm{p}<0.0001)$. The respective average values for density, standard error, minimum and maximum were (Figure $6 \mathrm{~b}$ ): $\mathrm{s}_{\mathrm{I}}, \mathrm{n}=12.00$ and $2.90 \pm 0.50$ $(0.60-5.60) ; \mathrm{s}_{\mathrm{II}}, \mathrm{n}=12.00$ and $0.47 \pm 0.26(0.00-2.80)$ and $\mathrm{s}_{\mathrm{III}}, \mathrm{n}=12.00$ and $2.53 \pm 0.58(0.00-6.80)$.

Probably, at the beginning of the settling process, recruits were distributed evenly on the substrate, and later, during size increase, they moved to the extremities. The adult specimens stayed in the extreme segments $\left(\mathrm{s}_{\mathrm{I}}\right.$ and $\mathrm{s}_{\mathrm{III}}$ ) and near the ring which fixes the substrate on the frames, where they clustered permanently, losing the movement of displacement. Similar behavior has been described for Mytilus edulis Linnaeus, 1758 (blue mussel), observed mainly in the adult individuals that aggregate and form dense beds. They have a limited capacity of movement, using their byssal threads (NRC, 2009). On the other hand, Perna perna (Linnaeus, 1758) (brown mussel) show a higher capacity of movement, using their byssal threads following the tide on coastal stones (Marques, 1988), but not forming mussel beds like $M$. edulis. This last species occurs on many kinds of substrate (bedrock, large to very large boulders, small boulders, muddy gravel, sandy mud, muddy sand, in 


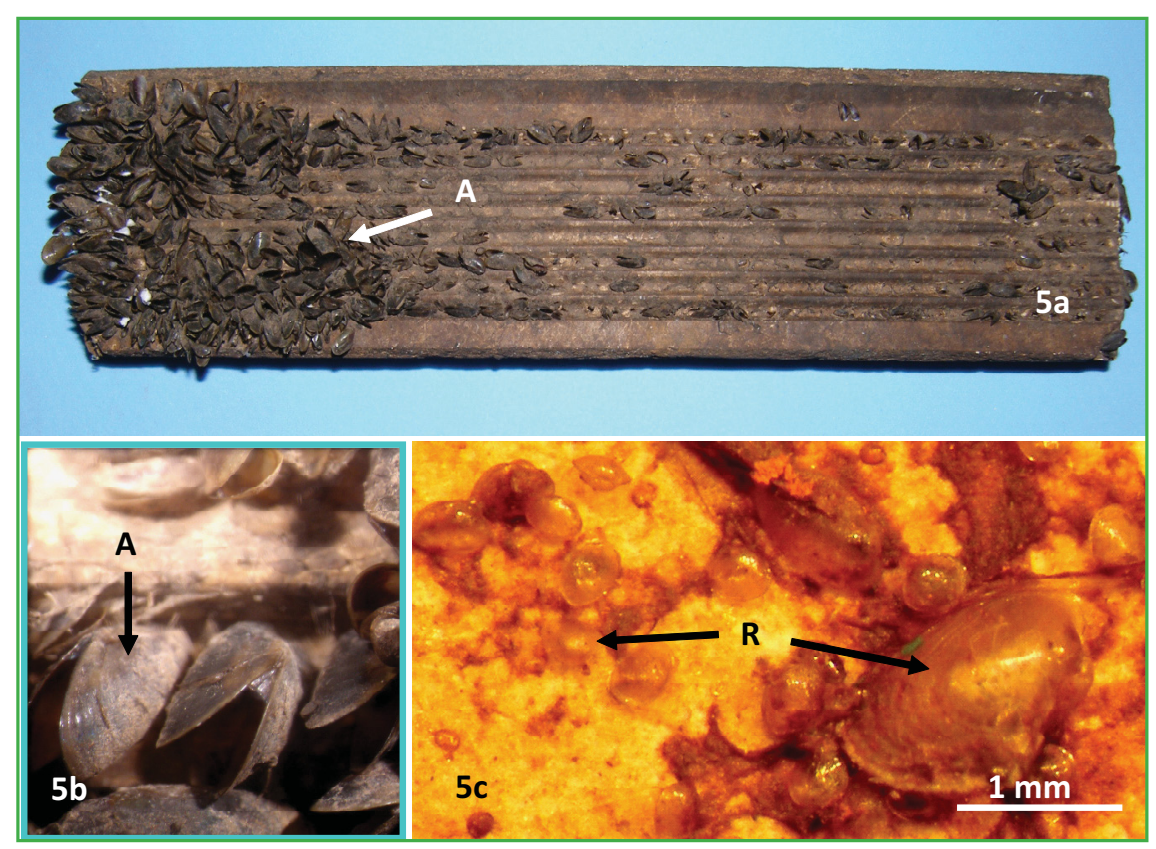

FIGURE 5: Golden mussel on pipe-shaped surface of the ceramic substrate: 5a, adult individuals (A) (substrate area: 21 x $6 \mathrm{~cm}$ ); $5 \mathrm{~b}$, adult individuals in the square $\left(1 \mathrm{~cm}^{2}\right) ; 5 \mathrm{c}$, recruits $(\mathrm{R})$.

rockpools, under boulders, in caves, etc.) (MARLIN, 2009). Limnoperna fortunei shows a similar behavior to M. edulis, forming large mussel beds mainly between rushes on sandy shores (Santos et al., 2008).

According to Uryu et al. (1996), the presence of clusters with large individuals indicates that the locality is probably advantageous for mussel settlement and growth.
Similar macrocluster formation and individual displacement (recruits and adults) patterns were also observed by Santos et al. (2008) in (ceramic and natural) substrate, on Veludo Beach (PV), at Guaíba Lake, Porto Alegre. The authors also verified that the individuals displacement movements decreased with the increase of size, and that the recruits sought protection under and among adult shells. According to Uryu et al. (1996) the presence of large individuals tends to cause movement

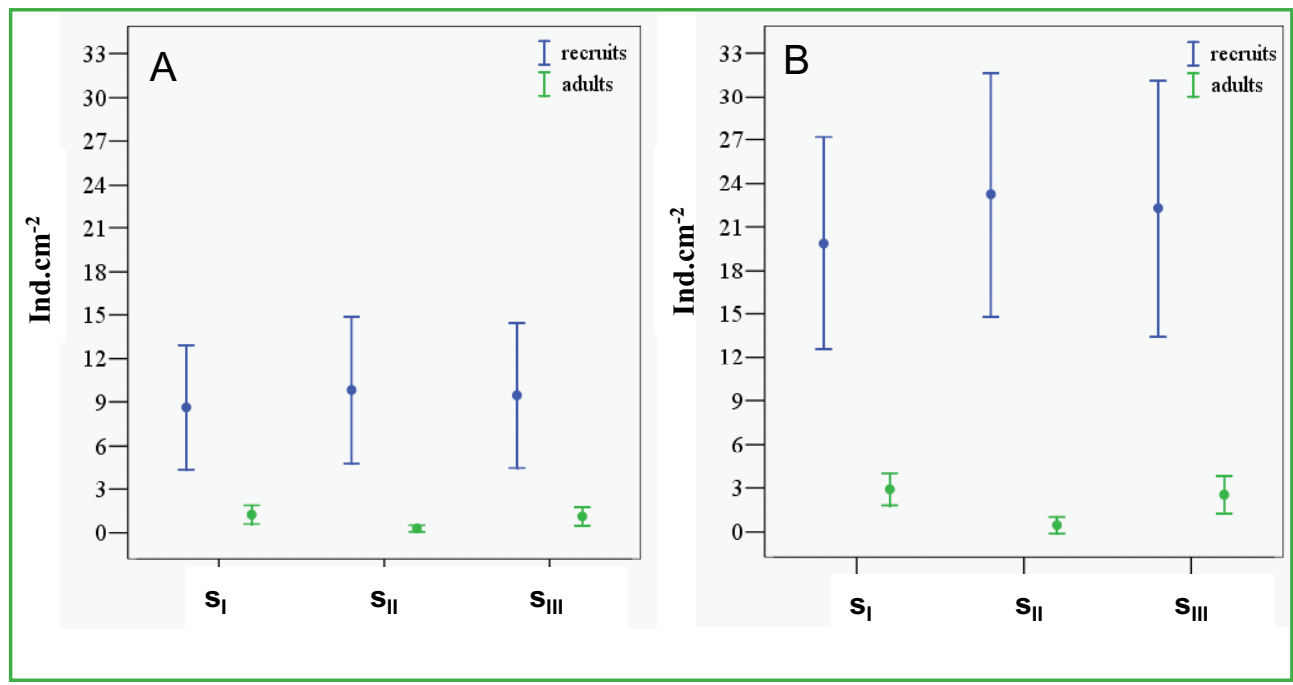

FIGURE 6: Average density (ind. $\mathrm{cm}^{-2}$ ) of golden mussel recruits and adults, with the respective standard error in the segments of the artificial ceramic substrates $\mathrm{s}_{\mathrm{I}}, \mathrm{s}_{\mathrm{II}}$ and $\mathrm{s}_{\mathrm{III}}$ : A, in the Jacuí Canal (CJ) and in the Port Docks (PO); B, in CJ only. 
cease and stimulates secretion of byssus threads by the smaller specimens.

The displacement of recruits seeking small clusters has been observed in some marine mytilids (Tan, 1975). Morton (1960) described a similar behavior for the bivalve Lasaea rubra (Montagu, 1803), due to the positive chemotaxis.

\section{Smooth versus pipe-shaped surface}

The sampling number, average recruit density (ind. $\mathrm{cm}^{-2}$ ), standard error and minimum and maximum values (Figure 7a) were, respectively: smooth surface, $\mathrm{n}=45.00$ and $7.19 \pm 1.59(0.00-44.00)$; pipe-shaped surface, $\mathrm{n}=45.00$ and $11.40 \pm 2.20(0.00-50.00)$. The Mann-Whitney test did not present any significant differences $(p=0.286)$ between the average densities of golden mussel recruits on smooth and pipe-shaped surfaces. When compared only to the average densities of the exposed substrates in CJ (Figure 7b), a significant difference $(p=0.04)$ between the smooth and pipeshaped surfaces of the artificial ceramic substrate was verified. The sampling number, recruit average density, standard error and minimum and maximum values were, respectively: smooth surface, $\mathrm{n}=18$ and $16.58 \pm 2.77$ (0.00 - 44.00); pipe-shaped surface, $\mathrm{n}=18$ and $26.99 \pm$ $2.72(8.80-50.00)$.
The predominance of recruits on the substrate's pipe-shaped surface may be related to greater protection. On the smooth surface, the recruits remained exposed to predators and to the water current. The pipe-shaped surface must offer similar protection to that found by recruits under and among the adults shells, at the start of settlement.

The adult individuals were present on both surfaces of the substrate. The sampling number, average adult density (ind. $\mathrm{cm}^{-2}$ ), standard error and minimum and maximum values were, respectively: smooth surface, $n$ $=45$ and $0.80 \pm 0.19$ (0.00 - 5.60); pipe-shaped surface, $\mathrm{n}=45$ and $0.98 \pm 0.25(0.00-6.80)$.

The Mann-Whitney test did not present any significant differences $(\mathrm{p}=0.925)$ between the average densities of $L$. fortunei recruits on smooth and pipeshaped surfaces (Figure 7a). When compared only to the average densities of the exposed substrates in $\mathrm{CJ}$ (Figure $7 b)$, no significant difference $(p=0.406)$ was observed between the surfaces. The sampling number, average density, standard error and minimum and maximum values were, respectively: smooth surface, $\mathrm{n}=18$ and $1.66 \pm 0.40$ (0.00 - 5.60); pipe-shaped surface, $\mathrm{n}=18$ and $2.28 \pm 0.49(0.00-6.80)$.

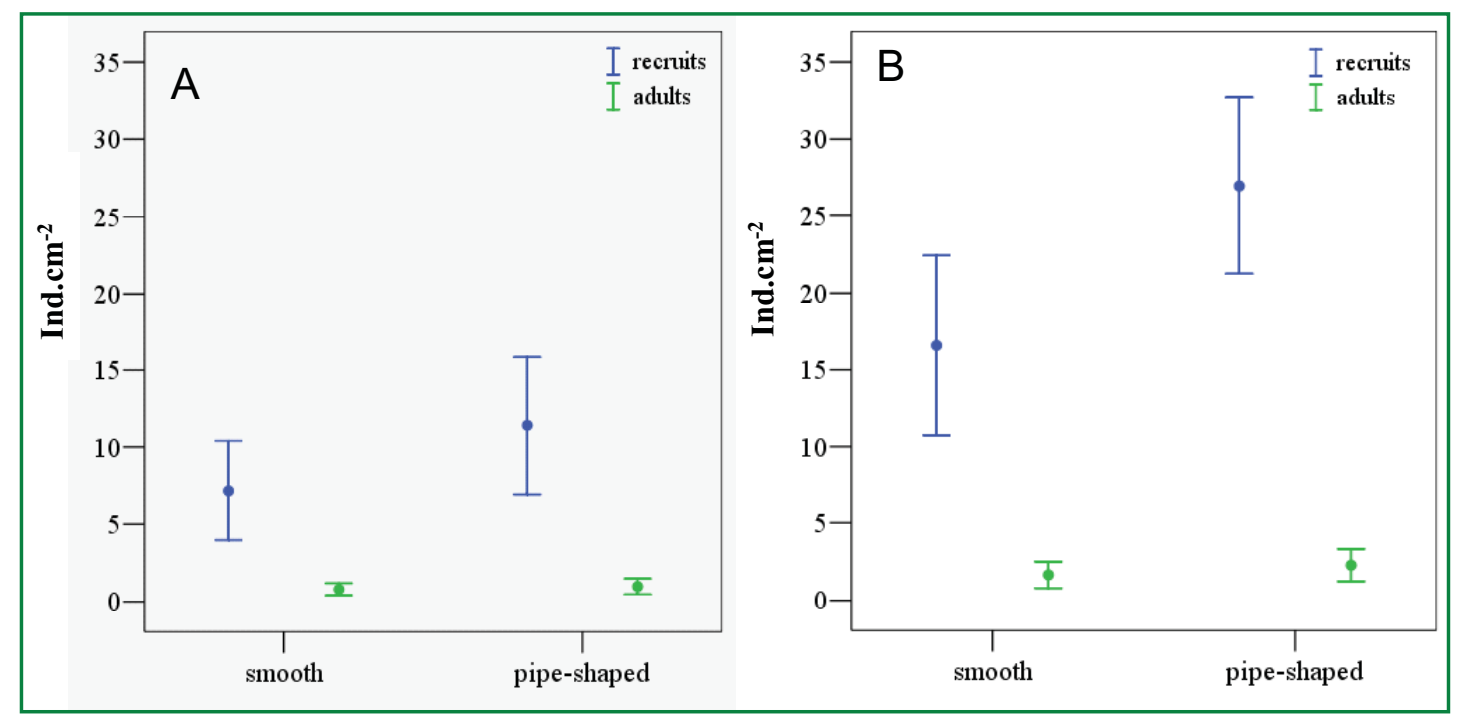

FIGURE 7: Average densities (ind.cm ${ }^{-2}$ ) of Limnoperna fortunei adults and recruits, with the respective standard error for smooth and pipeshaped surfaces, on artificial ceramic substrate. A, in the Jacuí Canal and in the Port Docks (PO); B, in CJ only. 
Santos et al. (2008) evaluated macroclusters in ceramic substrates (six-hole bricks) on PV, at Guaíba Lake, and verified that the mussels would rather encrust on the walls of the holes than on the substrate's outer surface.

Adequate surfaces, such as slits and grooves, are preferred by L. fortunei, determining the magnitude of the invasive species settlement (Morton, 1977). Morton (1977) confirmed that, in Hong Kong reservoirs, the invasive species first colonized surfaces with slits or grooves, and only later, smooth or exposed surfaces. This behavior was also verified by Uryu et al. (1996), mainly in younger individuals. In this study, a preference for surfaces similar to those reported by the above authors was verified. This preference is called "positive thigmotactism". Similar behaviour patterns were verified by Santos et al. (2008) for a lacustrine population of L. fortunei growing on marginal vegetation and by MARLIN (2009) for M. edulis settling in crevices and fissures on hard substrate.

\section{Sampling localities}

The average values, standard error, maximum and minimum values of water quality indicators are listed in Table 1.

The nitrate concentration $(p=0.04)$ and the fecal coliform densities $(p=0.03)$ were distinct in the sampling localities. In PO, the nitrate concentration and fecal coliform densities were higher due to the sewage release from the downtown Porto Alegre sewage system and the polluted waters of the Gravataí River, contaminated by the neighboring municipalities' sewage systems. Faria and Lersch (1998) and Bendati et al. (2003) carried out extended monitoring in the Jacuí River Delta and in the Guaíba Lake, respectively, and verified better quality waters (Class 2, according to CONAMA n.20, 1986) in $\mathrm{CJ}$ and inferior quality waters (Class 4) in PO.

The sampling number, the average recruit density (ind. $\mathrm{cm}^{-2}$ ), the standard error and the minimum and maximum values were, respectively (Figure 8): CJ, $\mathrm{n}=36$ and $21.78 \pm 2.11(0.00-50.00)$ and $\mathrm{PO}, \mathrm{n}=$ 54 and $0.96 \pm 0.14(0.00-5.40)$. The Mann-Whitney test presented significant differences $(\mathrm{p}<0.0001)$ between average densities of recruits in the sampling localities.

The sampling number, average adult density (ind. $\mathrm{cm}^{-2}$ ), standard error and minimum and maximum values were, respectively (Figure 8): CJ, $\mathrm{n}=36$ and $1.97 \pm 0.32$ $(0.00-6.80)$ and PO, $\mathrm{n}=54$ and $0.17 \pm 0.04(0.00-1.20)$. The Mann-Whitney test presented significant differences $(\mathrm{p}<0.0001)$ between average densities of adults in the sampling localities.

Recruit and adult maximum densities were observed in $\mathrm{CJ}$, where maximum values of larval densities occurred. In PO, some factors such as the significant formation of biofilms and the adherence of organic debris on the substrates, as well as the presence of oils deriving from ship leaks, must have contributed to the lowest recruit and adult densities (Figure 8).

TABLE 1: Water quality indicators (December 2005 to March 2006), on Canal, in the Pintada Island (CJ) and in the Port Docks (PO) (Jacuí River delta, Rio Grande do Sul State, Brazil): average standard error (minimum and maximum). Fecal coliforms (CF). Probability (p) obtained through the Mann-Whitney test when comparing to the sampling localities. Significant differences*.

\begin{tabular}{cccc}
\hline Indicators & $\mathbf{C J}$ & PO & p \\
\hline $\mathrm{T}\left({ }^{\circ} \mathrm{C}\right)$ & $27.6 \pm 0.7(26-29)$ & $28.4 \pm 0.6(27-30)$ & 0.56 \\
$\mathrm{pH}$ & $7.0 \pm 0.3(6.3-7.8)$ & $6.7 \pm 0.3(6.1-7.3)$ & 0.56 \\
$\mathrm{OD}\left(\mathrm{mg} \mathrm{O}_{2} / \mathrm{L}\right)$ & $6.8 \pm 0.9(5.1-7.9)$ & $6.4 \pm 0.6(5.5-7.5)$ & 0.66 \\
$\mathrm{DQO}\left(\mathrm{mg} \mathrm{O}_{2} / \mathrm{L}\right)$ & $17.5 \pm 7.2(10.0-39.0)$ & $17.7 \pm 7.1(9.6-39.0)$ & 0.88 \\
Total phosphorus $(\mathrm{mg} \mathrm{P} / \mathrm{L})$ & $0.12 \pm 0.06(0.05-0.32)$ & $0.18 \pm 0.07(0.08-0.40)$ & 0.20 \\
$\mathrm{NO}_{3}\left(\mathrm{mg} \mathrm{NO}_{3} / \mathrm{L}\right)$ & $0.73 \pm 0.18(0.32-1.20)$ & $1.61 \pm 0.36(0.83-2.57)$ & $0.04^{*}$ \\
$\mathrm{CF}(\operatorname{log~NMP} / 100 \mathrm{~mL})$ & $1.7 \pm 0.7(0.0-2.9)$ & $3.5 \pm 0.2(2.9-3.8)$ & $0.03^{*}$ \\
\hline
\end{tabular}




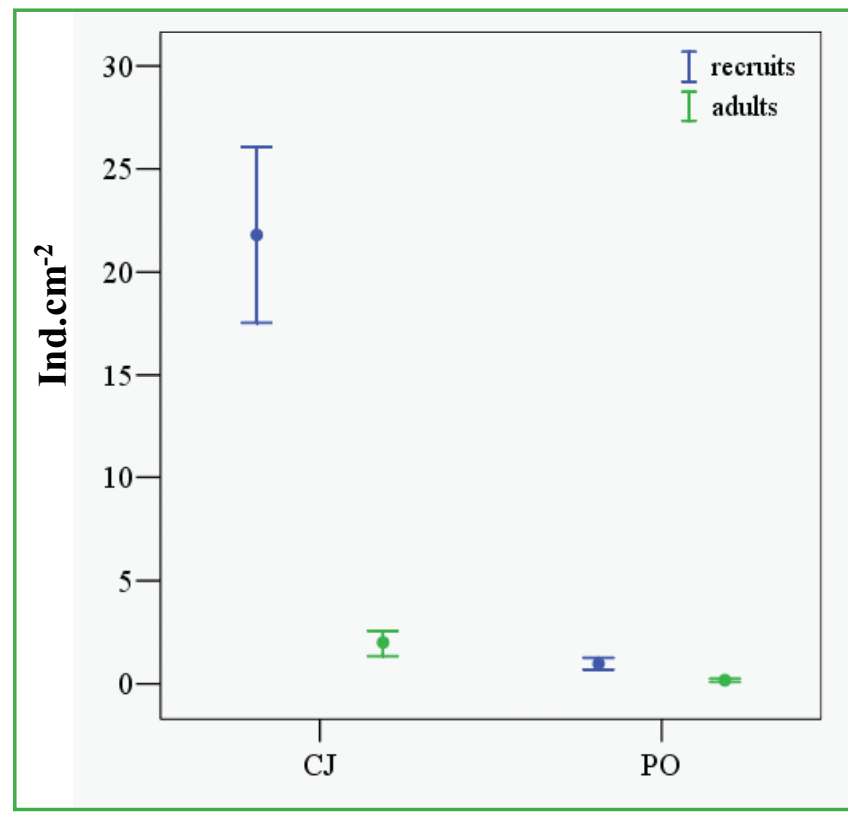

FIGURE 8: Average density (ind. $\mathrm{cm}^{-2}$ ) of adults and recruits with the respective standard error in the Jacuí Canal, on Pintada Island (CJ) and in the Port Docks (PO) (Jacuí River delta, Rio Grande do Sul state, Brazil).

The sampling number, total average density (recruit + adult: ind. $\mathrm{m}^{-2}$ ), standard error and minimum and maximum values for sampling localities were, respectively: $\mathrm{CJ}, \mathrm{n}=72$ and 118,800.00 $\pm 15,800.00$ $(0.00-500,000.00)$ and PO, $\mathrm{n}=108$ and 5,700.00 \pm $800.00(0.00-50,400.00)$. The total average densities (ind $\mathrm{m}^{-2}$ ) are similar to those data from previous monitorings (Darrigran and Mansur, 2006; Mansur et al., 2003; 2004; Santos, 2004).

\section{Recruits versus adults}

The sampling number, average density (ind. $\mathrm{cm}^{-2}$ ), standard error and minimum and maximum values were, respectively: recruits, $\mathrm{n}=90$ and $9.29 \pm 1.37(0.00$ $50.00)$ and adults, $\mathrm{n}=90$ and $0.89 \pm 0.16(0.00-6.80)$. The Mann-Whitney test presented significant differences $(p<0.0001)$ between the average densities of golden mussel recruits and adults (ind. $\mathrm{cm}^{-2}$ ) (Figure 9). This result represents what is expected, in other words, recruit numbers tend to be higher than the number of adults, since these are subject to population dynamics processes such as mortality.

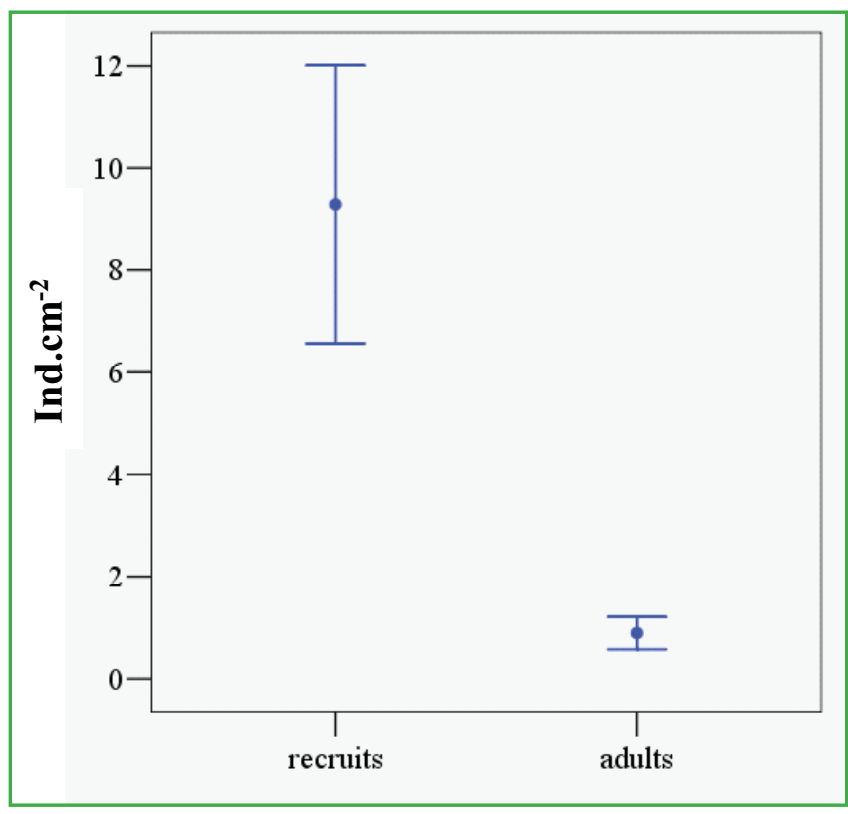

FIGURE 9: Average density (ind. $\mathrm{cm}^{-2}$ ) of adults and recruits with the respective standard error, Jacuí Canal and Port Docks.

The adult average densities verified in the ceramic substrate resulted from the period of exposure. Substrates exposed for a longer period sometimes present a different proportion of recruits and adults, as verified by Boltovskoy and Cataldo (1999) and Morton (1977). Elevated recruit densities are usually verified in the spring and summer, a period of greater settlement, while higher adult densities are observed in the fall and winter (Boltovskoy and Cataldo, 1999; Santos, 2004).

The presented method is efficient in the sampling and subsampling of golden mussel populations in lacustrine environments. But this method is also suggested for testing in different aquatic environments, mainly rivers with high speed flow, aiming at the identification of the hydrodynamic interferences and considering recruitment and substract stability.

\section{Acknowledgments}

The authors are grateful to CT-Hidro/CNPq (Fundo Setorial de Recursos Hídricos/Conselho Nacional de Desenvolvimento Cientifico e Tecnológico - National Council for Scientific and Technological Development) for their support (process n. 507675/2004-5). 


\section{References}

APHA. 2004. Standard methods for the examination of water and wastewater. American Public Health Association, Washington, New York, USA, 1368pp.

Bendati, M. M.; Schwarzbach, M. S. R.; Maizonave, C. R. M.; Bringhenti, M. L.; Almeida, L. B. 2003. Avaliação da qualidade da água do lago Guaíba: subsídios para a gestão da bacia hidrográfica. Ecos, 7: 1-34.

Boltovskoy, D.; Cataldo, D. H. 1999. Population dynamics of Limnoperna fortunei, an invasive fouling mollusc, in the Lower Paraná River (Argentina). Biofouling, 14 (3): 255-263.

Claudi, R.; Mackie, G.L. 1994. Practical manual for zebra mussel monitoring and control. $2^{\text {th }}$ ed. CRC Press, New York, USA, 227pp.

Darrigran, G.; Damborenea, C.; Greco, N. 2007. Freshwater invasive bivalves in man-made environments: A case study of larvae biology of Limnoperna fortunei in a Hydroelectric Power Plant in South America. AMBIO, 36 (7): 575-579.

Darrigran, G. E.; Mansur, M. C. D. 2006. Distribuição, abundância e dispersão. In: Darrigran, G. E. \& Damborenea, C. (Eds). Bioinvasion del mejillón dourado en el continente americano. Edulp, La Plata, Argentina, p.93-110.

Faria, C. M.; Lersch, E. C. 1998. Delta do Jacuí: Águas e sedimento. DMAE, Porto Alegre, Brasil, 56pp.

Faria, E. A.; Branco, J. R. T.; Campos, M. C. S.; Oliveira, M. D.; Rolla, M. E. 2006. Estudo das características antiicrustantes de materiais. Revista da Escola de Minas, 59 (2): 233-238.

Fontes, H. M.; Takeda, A.; Fugita, D. S. V. 2002. Experience in Itaipu Reservoir (Brazil) with artificial substrate (in situ): Is it the best way of monitoring an invading species like Limnoperna fortunei (Bivalvia, Mytilidae)? Proceedings of International Symposium on Reservoir Management in Tropical and SubTropical Regions, Foz do Iguaçu, Brasil, p. 673-679.

Gibbons, W. N.; Munn, M. D.; Paine, M. D. 1993. Guidelines for monitoring benthos in freshwater environments. Report prepared for Environment Canada, North Vancouver, B.C. by EVS Consultants, North Vancouver, B.C., Canada, 81pp.

Mansur, M. C. D.; Cardoso, F. R.; Ribeiro, L. A.; Santos, C. P.; Thormann, B. M.; Fernandes, F. C.; Richinitti, L. M. Z. 2004. Distribuição e consequências após cinco anos da invasão do mexilhão dourado, Limnoperna fortunei, no estado do Rio Grande do Sul, Brasil (Mollusca, Bivalvia, Mytilidae). Biociências, 12 (2): 165-172.

Mansur, M. C. D.; Pereira, D. 2006. Bivalves límnicos da bacia do rio dos Sinos, Rio Grande do Sul, Brasil (Bivalvia, Unionoida, Veneroida e Mytiloida). Revista Brasileira de Zoologia, 23 (4): 1123-1147.

Mansur, M. C. D.; Pereira, D.; Santos, C. P.; Bergonci, P. E. A.; Thormann, B. M.; Takeda, A. M. 2009. Colonização de substrato artificial de madeira pelo mexilhão dourado, Limnoperna fortunei (Dunker, 1857) (Bivalvia, Mytiloida, Mytilidae), no Delta do rio Jacuí (RS, Brasil). Biotemas, 22 (1): 75-80.

Mansur, M. C. D; Richinitti, L. M. Z.; Santos, C. P. 1999. Limnoperna fortunei (Dunker, 1857), molusco bivalve invasor, na bacia do Guaíba, RS, Brasil. Biociências, 7 (2): 147-150.
Mansur, M. C. D.; Santos, C. P.; Darrigran, G.; Heydrich, I.; Callil, C. T.; Cardoso, F. R. 2003. Primeiros dados quali-quantitativos do mexilhão dourado, Limnoperna fortunei (Dunker), no Delta do Jacuí, no Lago Guaíba e na Laguna dos Patos, Rio Grande do Sul, Brasil e alguns aspectos de sua invasão no ambiente. Revista Brasileira de Zoologia, 20 (1): 75-84.

MARLIN. The Marine Life Information Network. 2009. Common mussel Mytilus edulis: habitat preferences and distribution of adults, juveniles and larvae. Available at $<$ http:// www.marlin.ac.uk/species/adult_distrib_Mytilusedulis. htm>. Accessed on 9 de april 2009.

Marques, H. L. A. 1988. Considerações ecológicas sobre o mexilhão Perna perna Linnaeus, 1758, em bancos naturais da região de Ubatuba, São Paulo, Brasil. Dissertação de Mestrado, Universidade Estadual de Campinas, Brasil, 108pp.

Morton, B. 1977. The population dynamics of Limnoperna fortunei (Dunker, 1857) (Bivalvia: Mytilacea) in Plover Cove Reservoir, Hong Kong. Malacologia, 16 (1): 165-182.

Morton, J. E. 1960. The responses and orientation of the bivalve Lasaea rubra Montagu. Journal of Marine Biological Association of the United Kingdom, 39: 5-26.

NRC. Natural Resources Canada. 2009. Climate Change Impacts and Adaptation Program, Project A515. Available at <http://www.geog.mcgill.ca/climatechange/ ReportsMap/mussellRpt.pdf>. Accessed on 9 April 2009.

Pastorino, G.; Darrigran, G.; Martin, S.; Lunaschi, L. 1993. Limnoperna fortunei (Dunker, 1857) (Mytilidae), nuevo bivalvo invasor en água del rio de La Plata. Neotropica, 39 (101/102): 34.

Santos, C. P. 2004. Avaliação da densidade e crescimento populacional do mexilhão dourado Limnoperna fortunei (Dunker, 1857) em suas diferentes fases de vida no lago Guaíba, município de Porto Alegre, RS, como subsídios ao controle do bivalve invasor. Dissertação de Mestrado, Universidade Federal do Rio Grande do Sul, Brasil, 85pp.

Santos, C. P.; Mansur. M. C. D.; Würdig, N. L. 2008. Variações no comprimento dos indivíduos de uma população de mexilhão dourado, Limnoperna fortunei (Mollusca, Bivalvia, Mytilidae), ao longo do ano, na Praia do Veludo, Lago Guaíba, Rio Grande do Sul, Brasil. Revista Brasileira de Zoologia, 25 (3): 389-396.

Santos, C. P.; Würdig, N. L.; Mansur, M. C. D. 2005. Fases larvais do mexilhão dourado Limnoperna fortunei (Dunker) (Mollusca, Bivalvia, Mytilidae), na bacia do lago Guaíba, Rio Grande do Sul, Brasil. Revista Brasileira de Zoologia, 22 (3): 702-708.

Tan, W. H. 1975. The effects of exposure and crawling behavior on the survival of recently settled green mussels (Mytilus viridis L.). Aquaculture, 6: 357-368.

Terra, N. R.; Lemieszek, M. B; Lemos, C. T.; Leite, E. H. 2007. Presença de Limnoperna fortunei (Dunker, 1857) nas bacias hidrográficas do Uruguai e lago Guaíba, Rio Grande do Sul, Brasil. FEPAM em Revista, 1 (1): 12-19.

Uryu, Y.; Iwasaki, K.; Hinque, M. 1996. Laboratory experiments on behaviour and movement of a freshwater mussel, Limnoperna fortunei (DUNKER). Journal of Molluscan Studies, 62: 327 341.

Zar, J. H. 1999. Biostatistical Analysis. $4^{\text {th }}$ ed. Prentice Hall, New Jersey, USA, 663pp 